\title{
РОДИНА ГОШКЕВИЧІВ ТА ЇЇ ВНЕСОК У РОЗБУДОВУ НАЦІОНАЛЬНОЇ САМОСВІДОМОСТІ УКРАЇНЦІВ В УМОВАХ РОСІЙСЬКОЇ ІМПЕРІЇ ТА УСРР
}

\author{
Свген СІНКЕВИЧ \\ Інститут міжнародних відносин і політології Вищої Східноєвропейської державної школи \\ в Перемишлі (Республіка Польща), професор \\ ul. Tymona Terleckiego, 6, Przemyl, 37-700, Polska \\ e-mail:e.sinkevych@gmail.com \\ DOI: $10.15330 /$ gal.32.220-225 \\ ORCID: 0000-0001-5729-1644
}

\begin{abstract}
Віктор Іванович Гошкевич археолог, краєзнавець, музеєзнавець, видавець, завновник історикоархеологічного музею в Херсоні мало знаний у масштабах Украӥни. Він походив зі знаної родини професора богослов'я, ректора Киїської духовної семінарії. Разом із М. Грушевським слухав лекиії основоположника украӥнської класичної історичної та археологічної науки Володимира Антоновича. Опинившись у Херсоні він посів посаду секретаря Херсонського губернського статистичного комітету $i$, не обмежуючись державною службою, почав вивчати давню історію краю, здійснював археологічні пошуки, турбувався про збереження пам'яток. Неоиіненною є його роль в утвердженні української мови та історії у нижньому Подніпров 'i.
\end{abstract}

Ключові слова: Віктор Іванович Гошкевич, краєзнавець, Херсонщина.

Незважаючи на вагомий внесок у розвиток української культури та дослідження історії, Віктор Іванович Гошкевич (1860-1928) археолог, краєзнавець, музеєзнавець, видавець українофільської газети "Юг” (1898-1907), дійсний член Одеського товариства історії та старожитностей (1896р.), член-кореспондент Московського археологічного товариства (1914р.), дійсний член Археологічної комісії ВУАН, маловідомий загалу українського суспільства. Напередодні та в умовах державної незалежності його персоні все більшу увагу вділили професійні історики, музейники та краєзнавці ${ }^{1}$. Певним доповненням до них слугують відомості, які можна почерпнути з документів архівного зберігання та періодики ${ }^{2}$.

\footnotetext{
${ }^{1}$ Алексеева И. Л. Изучение первобытной эпохи Одесским обществом истории и древностей. В. И. Гошкевич. Проблемы археологии Северного Причерноморья : к 100-летию основания Херсон. музея древностей : тез. докл. юбил. конф. : в 3 ч. Херсон, 1990. Ч. 3. С. 65-67 ; Былкова В. П. Археологическая деятельность В. И. Гошкевича. Проблемы археологии Северного Причерноморья : к 100-летию основания Херсонского музея древностей : тез. докл. юбил. конф. Херсон, 1990. Ч. 3. С. 67-69 ; Водотика С. Г. Невтомний краєзнавець: Віктор Іванович Гошкевич. Південний архів. Історичні науки. 1998. № 6. С. 65-85 ; Гошкевич Віктор Іванович (1860-1928): наук.-допом. покажч. / ОУНБ ім. О. М. Горького; склад. Н. М. Диба, Г. П. Мокрицька. Херсон, 1993. 17 с. ; Кармазіна Н. Дослідник старожитностей Півдня України : Віктор Іванович Гошкевич (1860-1928). Краєзнавство. 2013. № 3. С. 61-64 ; Костенко А. В. "Гашкевичі", а не "Гошкевичі": білоруська гілка відомого українського роду. "Нове та традииійне у дослідженнях сучасних представників суспільних наук” : матеріали міжнародної науково-практичної конференції (м. Київ, Україна, 5-6 лютого 2016 року). Київ : ГО "Київська наукова суспільнознавча організація", 2016 ; Костенко А. В. Херсонский Археологический музей и его “семейная история”: семья как сеть научных коммуникаций в музейном деле. Гісторыя Магілёва: мінулае і сучаснасць : зборнік навуковых прац удзельнікаў IX Міжнар. навук. канф. (25-26 чэрвеня 2015 г., г. Магілёв). Магілёв, 2015. C. 59-65 ; Костенко А., Абікулова М. Антична колекція Херсонського обласного краєзнавчого музую. Історія становлення (1890-1960). Херсон, 2016 ; Костенко А., Шевченко А. "Одного роду, але не одного 3 тобою класу”: сприйняття жовтневого перевороту родом Гошкевичів. Краєзнавство. 2017. № 1-2. С. 62 72 ; Костенко А. В. Етапи розвитку лапідарної колекції Херсонського обласного краєзнавчого музею. Історичні і політологічні дослідження. 2014. № 3-4 ; Костенко А. В. Нариси історії Музею Херсонського губернського статистичного комітету (1890-1898). Питання історії науки і техніки. 2015. № 2 ; Ласінська М. Ю. Гошкевич В. І. в археологічному вивченні Миколаївщини. Науковий вісник Миколаӥвського держ. ун-ту ім. В. О. Сухомлинського. 2010. Вип. 329. С. 218-227 ; Пиворович В. Б. Виктор
} 
Віктор Гошкевич народився 9 березня 1860 р. в Києві, у родині професора (ректора) Київської духовної семінарії та протопросвітера і настоятеля церкви святих Костянтина та Олени Івана Антоновича Гошкевича (1824-1871), що викладав у семінарії логіку, латину, догматичне та моральне богослов'я. Батько Віктора Гошкевича був братом Осипа Антоновича Гошкевича (1814-1875) - першого російського дипломата у Японії, автора праць про Японію і Китай. Мати В.І. Гошкевича - Ганна Іванівна Веледницька-Гошкевич була власницею дерев'яного будинку в Києві. Окрім старшого брата Михайла (1853-?) у Віктора Гошкевича були мо-

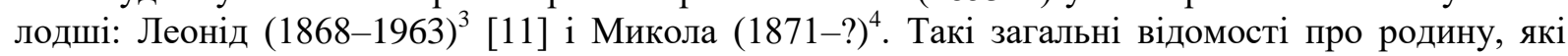
дійшли до нашого часу.

Студент і гуртківець В. Гошкевич разом із М. Грушевським слухав лекції основоположника української класичної історичної та археологічної науки Володимира Антоновича. Випускник духовної семінарії та Київського університету, очевидно не випадково був відібраний художником В. Васнецовим для позування при створенні образу Мойсея під час розпису Володимирського собору (1887р.), а ще раніше (1884р.) М. Врубель при розписі Кирилівської церкви, очевидно надав одному з апостолів риси обличчя Віктора Івановича. Доньку В. Гошкевича Катерину В. Васнецов увічнив як Святе маля на руках Богоматері у розписі Володимирського собору.

У 1881 р. Віктор Іванович Гошкевич одружився на Клавдії Олександрівній Бакановській. Сім'я В.І. Гошкевича вела скромну і в той же час наповнену бурхливими і цікавими подіями життя в середовищі київської богеми. У гостях у них бували літератори, поети, художники і вчені. Сам глава сімейства пристрасно захоплювався археологією і присвячував їй весь свій вільний час. Може, саме ця його пристрасть і слугувала причиною родинних непорозумінь? Сім'я В.І. Гошкевича розпалася у 1890 р., коли доньці Катерині було всього 8 років. Віктор Іванович зблизився з Варварою Амосівною Фабріциус, яка мала від першого шлюбу трьох дітей. Вслід за старшим братом, відомим губернським громадським діячем Михайлом Івановичем Гошкевичем, що починаючи з 1881 р. працював помічником губернського лікаря в Херсоні, у 1890 р. перебрався туди й Віктор Гошкевич. Із часом в Херсоні оселилися й молодші брати Леонід Іванович Гошкевич, що став пресвітером, та Микола Іванович Гошкевич, який переїхав сюди після служби начальником Ломжинської навчальної дирекції Варшавського округу5 .

Иванович Гошкевич - чины, награды, звания. Наукові записки : проблеми археології, етнографіï, icторії, історіографії, літературознавства, мистеитвознавства, музеєзнавства, ономастики, соиіології / Херсонський краєзнавчий музей. Херсон, 2004. С. 98-102 ; Пиворович В. Б. Сохранить для будущих поколений (по воспоминаниям Е. В. Гошкевич о Херсонском городском музее древностей). Наукові записки ХОКМ. Херсон : Айлант, 2006 : Сінкевич І. Ю. Внесок статистиків Херсонської губернії у дослідження історії краю (XIX - початок XX ст.). Південна Україна XVIII-XIX cm. : записки наук.-досл. лабораторії історії Південної України. Запоріжжя, 2000. Вип. 5. С. 171-176 ; Сінкевич I. Ю. Херсонська губернська вчена архівна комісія. Заселення Півдня Украӥни: проблеми наџіонального та культурного розвитку : наук. доп. Міжнарод. наук.-метод. конф. (Херсон, 21-24 трав. 1997 р.) : у 2 ч. Херсон, 1997. Ч. 1. С. 103-108 ; Сінкевич І. Ю. Херсонська губернська вчена архівна комісія : Нові знахідки та старі проблеми. Південний архів : історичні науки : зб. наук. праць. Херсон, 1999. Вип. 1. С. 18-40 ; Shevchenko A. Public activities of V. I. Goshkevych during the period of Revolution Scriptorium nostrum. 2015. № 3. P. 50-57.

2 Державний архів Херсонської області, ф. р 413 (Херсонский уездный отдел народного образования уездного исполкома. 1922 р.) оп. 1, спр. 408 (Личное дело заведуйщего музеем древности Гошкевича Виктора Ивановича) ; Класові вороги в археологічному музеї. Наддніпрянська правда. 1931. 21 січня ; Науковий архів Археологічних фондів Херсонського обласного краєзнавчого музею. Жизнеописание Фабрициус Ирины Васильевны / Ирина Фабрициус, Екатерина Гошкевич. 1983.

${ }^{3}$ Костенко А., Шевченко А. “Одного роду, але не одного з тобою класу”: сприйняття жовтневого перевороту родом Гошкевичів. Краєзнавство. 2017. № 1-2. С. 62-72.

${ }^{4}$ Костенко А., Абікулова М. Антична колекція Херсонського обласного краєзнавчого музею. Історія становлення (1890-1960). Херсон, 2016. С.10-14.

${ }^{5}$ Костенко А. В. “Гашкевичі", а не "Гошкевичі": білоруська гілка відомого українського роду. Нове та традиційне у дослідженнях сучасних представників суспільних наук : матеріали міжнародної науковопрактичної конференції (м. Київ, Україна, 5-6 лютого 2016 року). Київ : ГО “Київська наукова суспільнознавча організація", 2016. С. 65. 
Відразу по приїзді до Херсону, Віктор Іванович започатковує Археологічний музей Херсонського губернського статистичного комітету. Н. Кармазіна зазначає: “Яскравою постаттю, яка відіграла значну роль у розвитку пам'яткознавства Херсонщини, був Віктор Іванович Гошкевич. Приїхавши з Києва у 1890 р., він зайняв посаду секретаря Херсонського губернського статистичного комітету i, не обмежуючись державною службою, почав вивчати давню історію краю, здійснював археологічні пошуки, турбувався про збереження пам'яток"б. У 1893 р., коли справи приймав новий губернатор - Михайло Весьолкін (1842-1897), в організованому В. Гошкевичем Археологічному музеї Херсонського губернського статистичного комітету нараховувалася одна тисяча предметів ${ }^{7}$. М. Весьолкін офіційно звернувся до всіх землевласників, священиків, вчителів та інших освічених людей краю з проханням повідомляти про місцевості, що мають інтерес для археологічної науки, та надсилати до зростаючого херсонського музею свої випадкові знахідки старожитностей. На цей заклик справді відгукнулися в усіх куточках губернії. Тож В. Гошкевичу вдалося сформувати цілу мережу добровільних помічників, кількість яких незабаром сягнула ста осіб.

На початку 1897 р. для В. Гошкевича стало зрозумілим, що його колекції неможливо і далі тримати вдома та в приміщеннях Статистичного комітету через брак місця. Саме в цей час до нього й звернулися співдиректори Херсонської громадської бібліотеки Георгій Скадовський (який ще у 1886 р. розпочав археологічні дослідження на землях свого маєтку полизу Білозерки) і Володимир Синькевич ветеринарний лікар губернського земства (1859-? рр., якого у донесеннях Третього відділення поліції називали не інакше як “украинофильствующим поляком”), з пропозицією перемістити колекцію до приміщення новозбудованої бібліотеки (будівля збереглася, в ній знаходиться ЗАГС). Справа а тому, що дирекція бібліотеки мала зобов'язання перед одним зі своїх жертводавців облаштувати у своєму приміщенні археологічний музей імені князя Потьомкіна і спеціально для нього вже обладнала три кімнати з вогнетривкими підлогами та стелями й залізними дверима, але не мала жодного предмету, яким могла би заповнити цей простір. В той же час керівники бібліотеки, як і всі освічені херсонці, знали про те, що у В. Гошкевича зберігається велика кількість старожитностей, яку він не має де розмістити.

У 1895 р. у музеї побував професор Одеського Новоросійського університету О.М. Деревицький, який запропонуав передати усі зібрані колекції до Одеського міського музею старожитностей. Однак В.І. Гошкевич, сподіваючись залишити у Херсоні результати своєї праці, відмовився ${ }^{8}$. Його колекцію систематично поповнювали Імператорська Археологічна комісія, Б.В. Фармаковський, І.Я. Стемпковський. Впродовж 1913-1917 pр. до Херсонського музею старожитностей з Миколаєва надходили античні предмети від родини відомого українського мецената і історика Миколи Миколайовича Аркаса. На жаль, значна частина колекцій Аркасів археологічна, нумізматична, колекції зброї та картин - зникла під час Другої світової війни. Невелика частина колекції в Херсонських музейних фондах все ж збереглася. У складі археологічної колекції - це античні предмети зі Старої Богданівки та Христофорівки.

Упорядкуванням відділів музею займалися палеонтолог проф. М.В. Павлова, хранитель нумізматичного відділу Ермітажу О.Ф. Ретовський. Для ознайомлення з його експозицією спеціально приїздили редактор журналу "Praehistorische Zeitschsift" доктор К. Шухгардт (Берлін), доктор Драгендорф (Афіни), професор К.Ф. Кінг (Копенгаген), директор Стокгольмського музею старожитностей доктор Т. Арне, Одеського археологічного музею - А.І. Селінгінський, музею ім. О.М. Поля (Катеринослав) - професор Д.І. Яворницький.

Не менш плідною була діяльність В.І. Гошкевича як редактора щоденної газети "Юг”. “Аналіз статей газети дає яскравий опис громадянської позиції головного редактора. 3 наростанням суспільно-політичної кризи в Російській імперії матеріали представлені в газеті стали

\footnotetext{
${ }^{6}$ Кармазіна Н. Дослідник старожитностей Півдня України : Віктор Іванович Гошкевич (1860-1928). Краєзнавство. 2013. № 3. С. 61.

${ }^{7}$ Костенко А. В. Етапи розвитку лапідарної колекції Херсонського обласного краєзнавчого музею. Iсторичні і політологічні дослідження. 2014. № 3-4. С. 190.

${ }^{8}$ Костенко А. В. Нариси історії Музею Херсонського губернського статистичного комітету (1890-1898).

Питання історії науки і техніки. 2015. № 2. С. 51.
} 
більш радикальними щодо тогочасної влади. Багато уваги надавалося проблемам селянства, розвитку культури та історії. Особливо цікава позиція головного редактора щодо української мови та культури. На шпальтах газети можна знайти багато статей, присвячених цій темі, зокрема неодноразово друкувалися статті присвячені творчості Т.Г. Шевченка. Дослідницька діяльність вченого теж підтверджує його симпатію до української справи, а саме той факт, що найбільшим відділом Музею старожитностей був відділ Запорізької старовини. $€$ навіть спогади, що він найбільше його любив та розповідав про експонати так: “яскраво поставала в уяві та доба, та слава козача, що не можна було перевести дихання. Він тоді ніби палав якимось дивним внутрішнім вогнем". Критика самодержавства і лібералізм обходилась видавцеві газети досить дорого. Він був під постійним негласним наглядом поліції9. Політичні погляди В. Гошкевича, послуговування українською мовою обумовили заборону з 1905 р. на проживання в Херсоні, тому він змушений був оселитися в Голій Пристані.

У 1911 р. у Херсонському археологічному музеї відбулися чималі зміни. Музей, що до того розміщувався у кількох залах громадської бібліотеки, отримав від міського управління окремий двоповерховий будинок на центральній вулиці міста - Говарда. 3 цієї нагоди англійський науковець Е. Міннз надіслав до Херсона вітальну телеграму. В. Гошкевич пишався цим знаком уваги до його праці та опублікував текст телеграми поряд з іншими вітальними телеграмами, в "Херсонській міській газеті Копійка" - окремою заміткою "Привітання місту Херсон від англійського вченого" із зазначенням регалій автора привітання, а також у першому числі власного “Літопису Музею”. Визнання з боку авторитетних закордонних вчених було для В. Гошкевича важливим також через те, що як зазначено вище починаючи з 1905 р. він перебував у конфлікті з губернською владою, яка вбачала в ньому небезпечного ліберала та українофіла. Під час відкриття оновленого Музею старожитностей Херсонське міське управління навіть намагалося уникнути згадки про нього на урочистостях чи в публікаціях. Тож, попри те, що йому вдалося зберегти за собою завідування Музеєм старожитностей, В. Гошкевич піддавася сильному тиску з боку губернських та міських властей - i його зв'язки із закордоном додавали йому ваги у цьому протистоянні. У цій ситуації його контакти із закордонними вченими були свого роду оберегом. В. Гошкевич встановив і підтримував постійні наукові контакти з британським дослідником Елісом Міннзом. Від спілкування В. Гошкевича та Е. Міннза на сьогодні лишилася чи не єдина матеріальна реліквія - 720-ти сторінковий фоліант, що зберігається у спеціалізованій бібліотеці Херсонського обласного краєзнавчого музею. 9 березня 1926 р. директор Херсонського історично-археологічного музею Ірина Фабриціус придбала книгу Е. Міннза "Scythians and Greeks" для поповнення музейної бібліотеки. Видана в 1913 р., ця книга вже мала статус класичної узагальнюючої праці з історії скіфо-грецького періоду Північного Причорномор'я, тож мати іiї в музеї було необхідно. Але був й інший мотив - особистий. І. Фабриціус знала, що автор книги - кембриджський професор Еліс Міннз був особисто знайомий з ії прийомним батьком та попередником на посаді директора музею В. Гошкевичем. До того ж В. Гошкевич неодноразово згадувався на сторінках книги.

Але повернемося й до певних фрагментів приватного життя Віктора Івановича. На початку липня 1910 р. херсонська газета "Рідний край" повідомляла про приїзд до Херсона подружжя військового міністра Російської імперії Володимира Олександровича Сухомлинова (1848-1926) - Катерини Вікторівни (1882-1919?). Пані К. Сухомлинова прямувала в Голу Пристань, де в той час мешкав ії̈ батько Віктор Іванович Гошкевич. У Голій Пристані відбулася перша після кількох десятиліть розлуки зустріч батька і вже дорослої доньки. Втім, зустрічі цій судилося стати і останньою в їх житті.

У 1923 р. у діяльності музею відбулися значні зміни - його зарахували до централізованої мережі наукових музеїв УСРР під назвою Херсонського державного історично-археологічного музею. У квітні 1923 р. Ірина Василівна Фабриціус, прийомна донька та багаторічна помічниця В.І. Гошкевича, була офіційно призначена зберігачем фондів Херсонського історич-

\footnotetext{
${ }^{9}$ Костенко А., Шевченко А. “Одного роду, але не одного з тобою класу”: сприйняття жовтневого перевороту родом Гошкевичів. Краєзнавство. 2017. № 1-2. С. 68.
} 
но-археологічного музею, директором якого став іï батько. У 1925 р. В.І. Гошкевич важко хворий вийшов на пенсію. Директором музею стала І.В. Фабриціус. У 1927 р. разом з Георгієм Петровичем Крисіним І.В. Фабриціус працювала в складі Ольвійської експедиції10 .

У 1928 р. В.І. Гошкевич помер. Він був типовим представником тієї категорії дореволюційної наукової інтелігенції, яка і за радянської влади прагнула служити науці, вбачаючи в цій справі свій обов'язок перед народом.

Владою на могилі було встановлено величний монумент, але вже за кілька років щодо його найближчих учнів - колективу Херсонського історично-археологічного музею, розпочалися політичні утиски. Місцева газета "Наддніпрянська правда" опублікувала анонімну кореспонденцію. У ній, зокрема, стверджувалося: “Херсонський державний історично-археологічний музей, через засміченість його штату, за 13 років пролетарської диктатури не тільки не прилучився до завдань соціалістичного будівництва, а навпаки замкнувся у собі від пролетарської суспільності, у деяких галузях навіть свідомо шкодив" ". На думку автора кореспонденції, така ситуація в музеї стала можливою тому, що директорка цього закладу за соціальним походженням є “чужим елементом" і “вороже ставилася” до всіх починань радянської влади в музейній справі. У квітні 1931 р. І.В. Фабриціус звільнили з посади директора під час “чистки” за першою категорією. Передчуваючи неминучі подальші репресії І.В. Фабриціус, і ії співробітники та друзі - А.В. Добровольський та Г.П. Крисін покинули місто. Херсонський історично-археологічний музей було ліквідовано й на правах окремого Історичного відділу об'єднано 3 Природничим музеєм у Херсонський краєзнавчий музей.

\title{
THE HOSHKEVYCH FAMILY AND ITS CONTRIBUTION TO THE DEVELOPMENT OF NATIONAL CONSCIOUSNESS OF UKRAINIANS IN THE CONDITIONS OF THE RUSSIAN EMPIRE
}

\author{
Yevhen SINKEVYCH \\ Institute for International Relations and Political Science of the Higher Eastern European Public School in \\ Peremyshl (Poland), professor \\ Tymona Terleckiego St., 6, 37-700, Peremyshl, Poland \\ e-mail:e.sinkevych@gmail.com
}

\section{SUMMARY}

Viktor Ivanovych Hoshkevych - an archaeologist, ethnographer, museum expert, publisher, head of the historical-archaeological museum in Kherson, - isn't well known in Ukraine. He came from a well-known family of a theology professor, Rector of the Kyiv Theological Seminary. Invaluable is his role in establishing the Ukrainian language and history in the lower Dnieper.

Hoshkevych was the editor of the "Yug" newspaper. He spoke in favor of abolishing the ban on the Ukrainian language. Taras Shevchenko's poems were published in the newspaper. Hoshkevych criticized the Russian autocracy and was a supporter of liberal reforms. The museum created by Hoshkevych became the center of Kherson's cultural life. The scientist was acquainted with the English researcher E. Minz. Soon he received a book by E. Minz from "Scythians and Greeks".

Hoshkevich criticized autocracy and liberalism quite expensively. He was under constant police supervision. In 1928 V.I. Hoshkevych has died. He was the typical representative of that category of prerevolutionary scientific intelligentsia who, even under Soviet rule, sought to serve science, seeing in this case its duty to the people.

Keywords: Viktor Ivanovych Hoshkevych, regional ethnographer, Kherson region.

\section{REFERENCES}

Alekseeva Y. L. Yzuchenye pervobytnoi epokhy Odesskym obshchestvom ystoryy y drevnostei. V. Y. Hoshkevych. Problemy arkheolohyy Severnoho Prychernomoria : $k$ 100-letyiu osnovanyia Kherson. muzeia drevnostei : tez. dokl. yubyl. konf. : v 3 ch. Kherson, 1990. Ch. 3. S. 65-67.

\footnotetext{
${ }^{10}$ Костенко А., Абікулова М. Антична колекція Херсонського обласного краєзнавчого музую. Історія становлення (1890-1960). Херсон, 2016. С. 116-118.

${ }^{11}$ Класові вороги в археологічному музеї. Наддніпрянська правда. 1931. 21 січ.
} 
Bylkova V. P. Arkheolohycheskaia deiatelnost V. Y. Hoshkevycha. Problemy arkheolohyy Severnoho Prychernomoria : $k$ 100-letyiu osnovanyia Khersonskoho muzeia drevnostei : tez. dokl. yubyl. konf. Kherson, 1990. Ch. 3. S. 67-69.

Derzhavnyi arkhiv Khersonskoi oblasti, f. r 413 (Khersonskyi uezdnыi otdel narodnoho obrazovanyia uezdnoho yspolkoma. 1922 r.) op. 1. Spr. 408 (Lychnoe delo zaveduishcheho muzeem drevnosty Hoshkevycha Vyktora Yvanovycha).

Karmazina N. Doslidnyk starozhytnostei Pivdnia Ukrainy : Viktor Ivanovych Hoshkevych (18601928). Kraieznavstvo. 2013. № 3. S. 61-64.

Klasovi vorohy v arkheolohichnomu muzei. Naddniprianska pravda. 1931. 21 sichnia.

Kostenko A. V. "Hashkevychi", a ne "Hoshkevychi": biloruska hilka vidomoho ukrainskoho rodu. "Nove ta tradytsiine $u$ doslidzhenniakh suchasnykh predstavnykiv suspilnykh nauk" : materialy mizhnarodnoi naukovo-praktychnoi konferentsii (m. Kyiv, Ukraina, 5-6 liutoho 2016 roku). Kyiv : HO "Kyivska naukova suspilnoznavcha orhanizatsiia", 2016.

Kostenko A. V. Etapy rozvytku lapidarnoi kolektsii Khersonskoho oblasnoho kraieznavchoho muzeiu. Istorychni i politolohichni doslidzhennia. 2014. № 3-4.

Kostenko A. V. Khersonskyi Arkheolohycheskyi muzei y eho "semeinaia ystoryia": semia kak set nauchnykh kommunykatsyi v muzeinom dele. Historyia Mahilëva : minulae i suchasnasts : zbornik navukovykh prats udzelnikay̆ IX Mizhnar. navuk. kanf., 25-26 chervenia 2015 h., h. Mahilëv. Mahilëv, 2015. S. 59-65.

Kostenko A. V. Narysy istorii Muzeiu Khersonskoho hubernskoho statystychnoho komitetu (18901898). Pytannia istorii nauky i tekhniky. 2015. № 2.

Kostenko A., Abikulova M. Antychna kolektsiia Khersonskoho oblasnoho kraieznavchoho muzuiu. Istoriia stanovlennia (1890-1960). Kherson, 2016.

Kostenko A., Shevchenko A. "Odnoho rodu, ale ne odnoho z toboiu klasu": spryiniattia zhovtnevoho perevorotu rodom Hoshkevychiv. Kraieznavstvo. 2017. № 1-2. S. 62-72.

Lasinska M. Yu. Hoshkevych V. I. v arkheolohichnomu vyvchenni Mykolaivshchyny. Naukovyi visnyk Mykolaivskoho derzh. un-tu im. V. O. Sukhomlynskoho. 2010. Vyp. 329. S. 218-227.

Naukovyi arkhiv Arkheolohichnykh fondiv Khersonskoho oblasnoho kraieznavchoho muzeiu. Zhyzneopysanye Fabrytsyus Yryny Vasylevny / Yryna Fabrytsyus, Ekateryna Hoshkevych. 1983.

Pyvorovych V. B. Sokhranyt dlia budushchykh pokolenyi (po vospomynanyiam E. V. Hoshkevych o Khersonskom horodskom muzee drevnostei). Naukovi zapysky KhOKM. Kherson : Ailant, 2006.

Pyvorovych V. B. Vyktor Yvanovych Hoshkevych - chyny, nahrady, zvanyia. Naukovi zapysky : problemy arkheolohii, etnohrafii, istorii, istoriohrafii, literaturoznavstva, mystetstvoznavstva, muzeieznavstva, onomastyky, sotsiolohii / Khersonskyi kraieznavchyi muzei. Kherson, 2004. S. 98-102.

Shevchenko A. Public activities of V. I. Goshkevych during the period of Revolution Scriptorium nostrum. 2015. № 3. P. 50-57.

Sinkevych I. Yu. Khersonska hubernska vchena arkhivna komisiia : Novi znakhidky ta stari problemy. Pivdennyi arkhiv: istorychni nauky: zb. nauk. prats. Kherson, 1999. Vyp. 1. S. 18-40.

Sinkevych I. Yu. Khersonska hubernska vchena arkhivna komisiia. Zaselennia Pivdnia Ukrainy : problemy natsionalnoho ta kulturnoho rozvytku : nauk. dop. Mizhnarod. nauk.-metod. konf. (Kherson, 2124 trav. 1997 r.) : u 2 ch. Kherson, 1997. Ch. 1. S. 103-108

Sinkevych I. Yu. Vnesok statystykiv Khersonskoi hubernii u doslidzhennia istorii kraiu (XIX pochatok XX st.). Pivdenna Ukraina XVIII-XIX st. : zapysky nauk.-dosl. laboratorii istorii Pivdennoi Ukrainy. Zaporizhzhia, 2000. Vyp. 5. S. 171-176

Vodotyka S. H. Nevtomnyi kraieznavets: Viktor Ivanovych Hoshkevych. Pivdennyi arkhiv. Istorychni nauky. 1998. № 6. S. 65-85.

Hoshkevych Viktor Ivanovych (1860-1928) : nauk.- dopom. pokazhch. / OUNB im. O.M. Horkoho ; sklad. N. M. Dyba, H. P. Mokrytska. Kherson, 1993. 17 s. 